\title{
SIMPLE STRUCTURES TEST FOR ELASTIC-PLASTIC STRAIN ACCEPTANCE CRITERION
} VALIDATION

$$
\text { CONF-96/105-- }
$$

Thomas F. Trimble, Gregory R. Krech

\author{
November 1996
}

\section{NOTICE}

This report was prepared as an account of work sponsored by the United States Government. Neither the United States, nor the United States Department of Energy, nor any of their employees, nor any of their contractors, subcontractors, or their employees, makes any warranty, express or implied, or assumes any legal liability or responsibility for the accuracy, completeness or usefulness of any information, apparatus, product or process disclosed, or represents that its use would not infringe privately owned rights.

DISTPIBUTION OF THSS DOCUMENT IS UNHMMTED

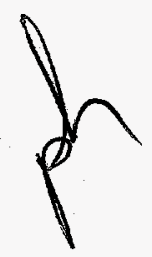

MASTER

KAPL ATOMIC POWER LABORATORY

Operated for the U. S. Department of Energy

by KAPL, Inc. a Lockheed Martin company 


\section{DISCLAMMER}

This report was prepared as an account of work sponsored by an agency of the United States Government. INeither the United States Government nor any agency thereof, nor any of their employees, makes any warranty, express or implied, or assumes any legal liability or responsibility for the accuracy, completeness, or usefulness of any information, apparatus, product, or process disclosed, or represents that its use would not infringe privately owned rights. Reference herein to any specific commercial product, process, or service by trade name, trademark, manufacturer, or otherwise does not necessarily constitute or imply its endorsement, recommendation, or favoring by the United States Government or any agency thereof. The views and opinions of authors expressed herein do not necessarily state or reflect those of the United States Government or any agency thereof. 


\section{DISCLAIMER}

Portions of this document may be illegible electronic image products. Images are produced from the best available original document. 


\title{
SIMPLE STRUCTURES TEST FOR ELASTIC-PLASTIC STRAIN ACCEFTANCE CRITERION VALIDATION
}

\author{
Thomas F. Trimble \\ Electric Boat Corporation \\ Groton, CT \\ Gregory R. Krech \\ Wyle Laboratories, Inc. \\ Huntsville, AL
}

\begin{abstract}
A Simple Structures Test Program was performed where several cantilevered beam and fixed-end beam test specimens were subjected to a series of analytically predetermined rapidly applied transient dynamic input loads. The primary objective of the test program was to obtain dynamic nonlinear response for simple structures subjected to these load inputs. Data derived from these tests was subsequently used to correlate to analysis predictions to assess the capability to analytically predict elastic-plastic nonlinear material behavior in structures using typical time-dependent (transient) design methods and the ABAQUS finite element analysis code.

The installation of a significant amount of instrumentation on these specimens and post-test measurements enabled the monitoring and recording of strain levels, displacements, accelerations, and permanent set. An assessment of modeling parameters such as the element type and mesh refinement was made using these test results. In addition, currently available material models and the incremental time step procedure used in the transient analyses were evaluated.

Comparison of test data to analysis results shows that displacements, accelerations, and peak strain can be predicted with a reasonable level of accuracy using detailed solid models of the tested specimens. Permanent set is overpredicted by a factor of approximately two. However, the accuracy of the prediction of permanent set is being enhanced by updating material modeling in the ABAQUS code to account for effects of strain reversal in oscillatory behavior of dynamically loaded specimens.
\end{abstract}

\section{INTRODUCTION}

The Simple Structures Test Program was proposed to obtain nonlinear response data, including plastic strain response, for use in nonlinear transient dynamic analysis/test correlation studies for structures fabricated from HY-80 steel. The primary objective was to obtain dynamic nonlinear response data (accelerations, strains, and displacements) for simple structures subjected to two different types of load input:

- a high peak acceleration amplitude of short cluration, and - a lower peak acceleration amplitude of longer duration.

These tests were performed to demonstrate the ability to conservatively predict elastic-plastic nonlinear material behavior in structures using typical design methods and currently available finite element analysis codes. Strain data in the plastic range of a material is not generally available from past dynamic load tests since strain gages are not typically used to record plastic action during dynamic load qualification or testing.

In finite element modeling for dynamic loading, the number and position of nodes, use of different element types, material behavior models, and analysis parameters can influence analysis results. As an analysis solution progresses, calculated results for a transient event become increasingly sensitive to modeling assumptions (including material representation) since potential errors are inherently cumulative. Data from this test were used to refine and verify general modeling and analysis assumptions resulting in a higher level of confidence in nonlinear transient dynamic analysis techniques.

Tested specimens consisted of cantilevered (Figure 1) and fixedend (Figure 2) beam structures fabricated from HY-80 steel. Both specimens were designed for low frequency response with fundamental frequencies of $10.1 \mathrm{~Hz}$ for the cantilever and $8.8 \mathrm{~Hz}$ for the fixed-end beam. Specimens were also designed such that, under the prescribed dynamic load, maximum surface strain would approach or exceed the $2.4 \%$ limit from the criterion in Reference (1) $\left(0.3 \varepsilon_{\mathrm{u}}\right.$, where $\varepsilon_{\mathrm{u}}$ is the ultimate strain value, $8.0 \%$ for $\mathrm{HY}-80$ ).

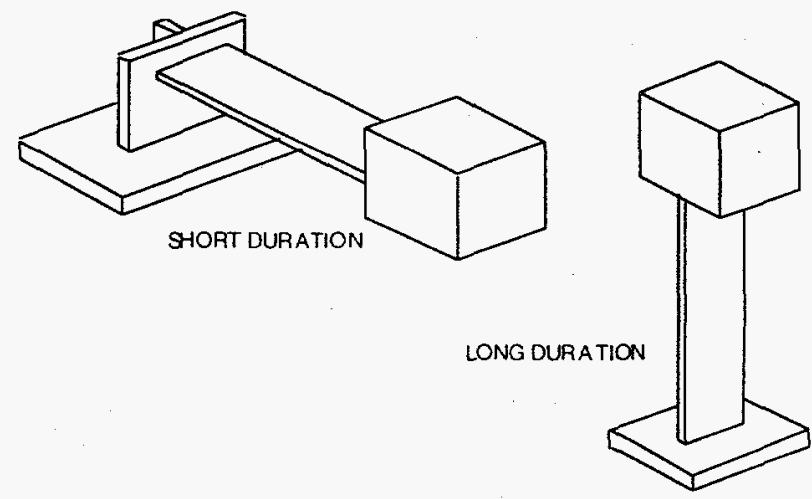

\section{FIGURE 1 Cantilevered Beam Assemblies}

Separate tests were required for each loading type. The first input had a high peak acceleration amplitude of short duration; the second input had a lower peak acceleration amplitude of longer duration. 
Both loadings were separately applied to the cantilevered test specimens. Specimens CS-1 through CS-7 were used for short duration loading. An Avco Drop Table test machine was selected for short duration testing. Specimens CL-1 through CL-3 viere used for long duration loading. The fixed-end beam specimen was only tested for the long duration loading (specimens BL-1 through BL-3) since the size and weight of the fixed-end beam specimen exceeded the short duration test machine capacity. A Parallel Pendulum test machine was selected for long duration testing.

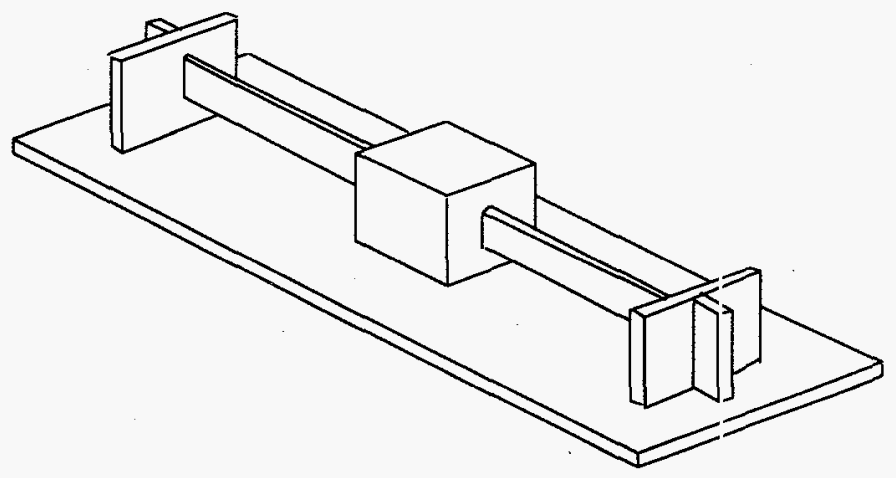

FIGURE 2 Fixed-End Beam Assembly

Elastic-plastic analyses using the ABAQUS nonlinear finite element code were performed to design the test specimens and to predict the dynamic structural response. The analytical results were correlated with test results initially at the test site to ensure test validity and later in more detail to assess accuracy. Strain values were analytically predicted at points on the test specimens that coincided with strain gage locations. Acceleration and displacement time histories were also used in the test correlation. As part of this test program, actual stress-strain properties were determined from material specimens taken from a sample of the plate used to fabricate the specimens that experienced the plastic deformation.

\section{TEST METHODS}

Test specimens and fixtures were fabricated using nomal fabrication and welding techniques. In order that material properties from the actual beam element be used in the correlation efforts, tensile specimens per ASTM E8 were taken from the plate used to fabricate the test specimen beam members. The resulting true stresstrue plastic strain curves were used for elastic-plastic analysis correlation.

Prior to testing, each specimen was subjected to a dimensional inspection using a Sheffield Model No. RM50 Coordinate Measuring Machine (CMM) at the test laboratory. For each specirnen, the locations of pre-selected points were measured and recorded. At the conclusion of each test, each specimen was measured or the CMM, thereby making available a tinal record of the deformed shape.

The Parallel Pendulum and Avco Drop Table machines were used for all testing. The required dynamic input was calibrated by combining the appropriate layers of programming materials at the proper table release height and performing test impacts with equivalent dummy masses secured to the table. Both calibration and actual test impacts were monitored by an accelerometer mounted directly on the test table. The desired dynamic input values for each of the tests was an idealized half-sine impulse. Peak acceleration level and pulse duration for baseline inputs for the correlation tests are listed in Table 1.

\section{TABLE 1 Idealized Dynamic Pulse Input}

\begin{tabular}{|c|c|c|c|}
\hline $\begin{array}{c}\text { SPECIMEN } \\
\text { TYPE }\end{array}$ & $\begin{array}{c}\text { INPUT } \\
\text { DURATION }\end{array}$ & $\begin{array}{c}\text { PEAK } \\
\text { "g" }\end{array}$ & $\begin{array}{c}\text { PULSE } \\
\text { WIDTH (msec) }\end{array}$ \\
\hline \hline FIXED-BEAM & LONG & 17 & 60 \\
\hline CANTILEVER & LONG & 20 & 60 \\
\hline CANTILEVER & SHORT & 70 & 12 \\
\hline
\end{tabular}

The Parallel Pendulum test table impacted the reaction mass, rebounded, and impacted again several times before damping out. There was no means to arrest the platform to prevent this repeated input. However, these additional impacts were acceptable since all critical data had already been recorded before the secondary impacts occurred. In addition, the subsequent impacts were less severe than the initial and caused no additional permanent set. The drop table machine utilized pneumatic arresting devices on the guide poles. These were activated by a trip switch such that no secondary impact occurred on this machine.

All instrumentation was connected to the applicable data monitoring and recording devices. Each test was preceded by a low intensity test impact. Data was monitored and recorded to ensure correct mounting of the specimen, correct performance of all data channels, and to confirm the expected specimen response through on-site elastic correlation of strains, accelerations, and deflections (long duration specimens only). Mounting bolts for all specimens were tightened to a predetermined level.

Nondestructive testing (NDT) of the welds in all test specimens was performed by qualified personnel following each test. Weld NDT consisted of visual (VT) and magnetic particle (MT) inspections. Permanent set displacement measurements of the test specimens were obtained.

A low level static load test was performed on cantilevered beam specimen CS-2 prior to being tested at the full level correlation load. This test was performed to obtain strain and displacement data for an instrumented specimen undergoing purely elastic behavior. Response data was recorded and digitized for the low level dynamic test performed on cantilevered beam specimen CS-7. A predetermined load of $5.8 \mathrm{~g}$ 's was applied such that dynamically-induced elastic strains resulted.

\section{INSTRUMENTATION}

Strain gages were selected and located in an attempt to optimize the data compiled. Strain gages were located to record strain at critical points on the structure. They were applied on opposite surfaces of the beam members to monitor bending strains that would best provide necessary data for adequate correlation to analysis. Ten element strings were used to measure strain gradients. High elongation gages were used to record anticipated high levels of strain. Rosettes were used to record bi-axial states of strain in the specimen. Accelerometer locations were selected to monitor input at the fixture-specimen locations and measure any uneven loading or mass block rotations. A linear variable differential transformer (LVDT) was selected to monitor linear displacement of the fixed-end beam (mass block) and curvilinear motion of the cantilever beam (mass block) during long duration load testing. The sensor types 
used in the test are listed in Appendix Table A-1. Representative strain gage mounting locations are shown in Appendix Figure A-1.

\section{DATA ACQUISITION}

Monitored test data was available for evaluation imnediately following each test at the predetermined critical sensor. All output from the instrumentation, including strain gages, response accelerometers, the LVDT signal, and control accelerometer was recorded in unfiltered form on TEAC XR 9000 tape decks. The analog data was initially anti-alias filtered at $8,000 \mathrm{~Hz}$. The test data was digitized at a sampling rate of $25,000 \mathrm{~Hz}$ for a duration of 1.0 second (minimum) starting just prior to the initial impact of the test table. Digital data files in ASCII format were recorded on an $8 \mathrm{~mm}$ magnetic data cartridge tape using UNIX/TAR format.

\section{TEST RESULTS}

A summary of measured peak specimen response is presented in Appendix Table A-2. Results are summarized as follows.

\section{Long Duration Cantilever}

The first test resulted in values of strain and permanent set at the lower end of the range of anticipated values. Upon closer evaluation of the input curves, it was determined that the profile of the curve was broader at the base and slightly steeper and narrower at the waist than an idealized curve (Figure 3). A determination was made that for the subsequent impacts, the input curve would be evaluated for impulse, represented by total area under the curve, in acldition to peak acceleration level and pulse duration.

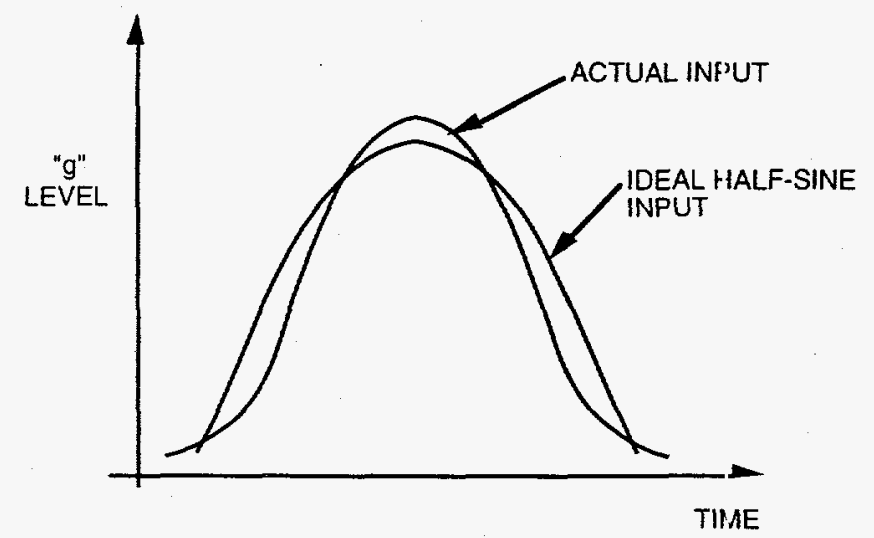

FIGURE 3 Actual vs. Ideal Input Pulse Curve

\section{Fixed-End Beam}

The fixed-end beam assemblies utilized a common base plate. As a result of welding the two beam end fixtures, some distortion of the base plate resulted. Since the base plate was not flat, securing the plate to the test platform by tightening the bolts resulted in some initial strain in the beam elements. To record any prestrain due to this base plate bolt tightening force, pre- and post-test readings of strain were taken.

The pendulum sled platform was suspended from above by steel cables attached to a steel framework. As such, the sled did not strike the impact mass evenly. In addition, some rebounding of the sled platform occurred after impact. The imbalance in impact loading was recorded by the accelerometers mounted at different locations on the test fixture.

The input load was determined by integrating the area under the load input curve in the same manner as for the cantilever test. Test specimens BL- 1 and BL-2 were subjected to the same load magnitudes in order to provide a repeated test. Both of these tests resulted in approximately the same amount of permanent set $(0.213$ and 0.224 inches, respectively). The remaining fixed beam assembly was tested at an increased level of load. Subjecting the BL3 specimen to an increased load level (29.2 peak " $g$ " vs. 22.8) resulted in larger strain values and greater permanent set $(0.389$ inches).

\section{Short Duration Cantilever}

The short duration cantilever test load was calibrated by using the same curve area integration method described for the long duration cantilever. After specimen CS-1 was tested, it was determined that an increased level of load was required to obtain strains approaching the goal of $2.4 \%$. The test of specimen CS-1 resulted in a peak strain level of $1.89 \%$. The next two specimens tested, CS-2 and CS-3, were subjected to loads $22 \%$ higher than the initial short duration test. These two tests resulted in peak strains over the target value and permanent set values of 0.828 and 0.898 inches, respectively, versus 0.287 inches for the initial short duration test.

The final two specimens, CS-6 and CS-7, were subjected to multiple impacts of equal magnitude. CS- 6 underwent ten impacts of 100 "g" peak acceleration and CS-7 underwent six impacts of approximately 160 " $\mathrm{g}$ " peak acceleration. The initial test impacts from these two assemblies enabled an assessment to be made of previously untested specimens subjected to increased load intensity.

A tabulation of short duration specimens, listed in the order of ascending strain and permanent set, is presented in Table 2 . This listing tabulates the initial (first hit) dynamic input for each of these short duration specimens. It is presented to illustrate the trend of increasing strain and permanent set as a function of " $\mathrm{g}$ " level and impact duration.

\section{TABLE 2 Short Duration Specimen Summary}

\begin{tabular}{|c|c|c|c|c|c|}
\hline \multirow{3}{*}{$\begin{array}{l}\text { TEST } \\
\text { SPEC }\end{array}$} & \multicolumn{5}{|c|}{ MEASURED PEAK } \\
\hline & \multicolumn{3}{|c|}{ LOADLEVEL } & \multirow[b]{2}{*}{$\begin{array}{c}\text { STRAIN } \\
(\%) \\
\end{array}$} & \multirow{2}{*}{$\begin{array}{c}\text { PERM. } \\
\text { SET } \\
\text { (in) } \\
\end{array}$} \\
\hline & $\begin{array}{c}\text { MAX } \\
" \mathrm{~g} " \\
\end{array}$ & $\begin{array}{r}\text { TIME } \\
(\mathrm{msec}) \\
\end{array}$ & $\begin{array}{c}\text { AREA } \\
\text { (in/sec) } \\
\end{array}$ & & \\
\hline CS-1 & 88.3 & 12 & 214.4 & 1.89 & 0.287 \\
\hline $\mathrm{CS}-2$ & 106.5 & 12 & 261.5 & 2.73 & 0.828 \\
\hline $\mathrm{CS}-3$ & 107 & 12 & 258.0 & 2.60 & 0.898 \\
\hline CS-6 & 100 & 10 & 254.1 & 2.87 & $1.16 *$ \\
\hline $\mathrm{CS}-7$ & 158 & 9 & 340.0 & 4.17 & $2.66 *$ \\
\hline CS.4 & 226 & 7 & 365.5 & 4.45 & 2.790 \\
\hline CS-5 & 742 & 3 & 347.8 & 5.23 & 3.408 \\
\hline
\end{tabular}

* permanent set from initial shot (field measured)

Accumulated permanent set was substantial. A summary of the multiple hit specimen results for accumulated permanent set is listed in Table 3. Upon review of the data in the table, it is apparent that strain hardening of the specimens occurs as the change in permanent 
set between successive impacts decreases. At no time during these multifle shor iests did structural failure occur.

\section{IABLE 3 Cumulative Permanent Set for Multiple Shot Tests}

\begin{tabular}{|c|c|c|c|c|}
\hline \multirow{2}{*}{$\begin{array}{l}\text { SHOT } \\
\text { NO. }\end{array}$} & \multicolumn{2}{|c|}{$\begin{array}{c}\mathrm{CS}-6,100 \mathrm{~g}^{\circ} \mathrm{s} \\
\text { (a } 10 \mathrm{msec}\end{array}$} & \multicolumn{2}{|c|}{$\begin{array}{c}\mathrm{CS}-7.100 \mathrm{~g} \text { 's } \\
@ 9 \mathrm{msec}\end{array}$} \\
\hline & $\begin{array}{l}\text { DELTA } \\
\text { (in) }\end{array}$ & $\begin{array}{l}90 \text { OF } \\
\text { TOTAL }\end{array}$ & $\begin{array}{l}\text { DEITA } \\
\text { (in) }\end{array}$ & $\begin{array}{l}\% \% \overline{O F} \\
\text { TOTAL } \\
\end{array}$ \\
\hline 1 & 1.16 & 22 & 2.66 & 32 \\
\hline 2 & 2.06 & 39 & 4.72 & $\leq 7$ \\
\hline 3 & 2.75 & 52 & 6.19 & 75 \\
\hline 4 & 3.25 & 62 & 7.19 & 57 \\
\hline 5 & 3.69 & 70 & 7.88 & $\$ 6$ \\
\hline 5 & 4.06 & 73 & 8.25 & 100 \\
\hline 3 & 4.44 & 85 & - & $\therefore$ \\
\hline 6 & 4.75 & 90 & - & $\therefore$ \\
\hline 9 & 5.06 & 96 & - & $=$ \\
\hline 10 & 5.25 & 100 & - & . \\
\hline
\end{tabular}

\section{Low Level (Elastic) Static And Dynamic Tests}

Before being dynamically tested. specimen CS-2 was statically loaded with a weight of 205 lbs. This resulted in a static deflection of 0.625 inch with strains of $0.13 \%$. The CS.7 specimen was dyramicaliy tested to a $5.8 \mathrm{~g}$ load. This resulted in low level strains that were within the elastic range $(0.18 \%$ peak $)$. The results of these two tests were used in correlation of elastic strain values and arc presented in Reference (2).

\section{POST-TEST DATA}

Measurements of post-tcst deformations of the test specimens were recorded by the testing laboratory on the CMM machine. These deformations were recorded as part of the output and the post-test deformed shapes were used in the correlation of test results presented in Reference (2). Video recordings at both regular and high speed were taken for all tests.

\section{CONCLUSIONS}

This test program resulted in a concise body of experimental data using sufficiently instrumented test specimens that can be used with confidence to correlate analysis results to test data. The structures used in the test represented initially unstrained (i.e.. untested) specimens that experienced mitial plastic stram and subsequent aiternatung tension-comprcssion strain cycles when subjected to dynamic loading. Structural spectmens were subjected to a controlled input pulse.

The specimens used in this test program wese fabricated from HY80 steel. Based on the acquired data. an accurate assessment can be made of:

- The abildty to conservatively predict elastic-plastic structural response under dynamic loading;

- The margin-to-failure of the Reference (1) strain limits; and

- Location of maximum strain and shape of strain gradient in relation to specimen geometry such as with the presence of a reinforcing fillet.

Although the tests involved cost-effective, simple structural models, an increased level of confidenec in nonlinear analyrical methods was obtaincd. The tests crabled strain levels, displacements, accelerations, and fundamental modal respunics to be monitored. The tests also demonstrated the capability of currently used nonlinear finite clement analysis codes to accurately analyze these types of problems. A thorough assessment of corrclation of tcst results to analysis is presented in Reference (2).

Typical plate modeling and analysis practices wcre shown to capture peak displacement and acceleration responses, as well as to provide a conservative approximation of pcak strain levels. Detailed solid (including fillet weids) models were demonstrated to accurately predict peak strains as well as their locations. The detailed soild model would be used only when the rypical plate model could not demonstratc adequacy.

The predictions of permasent set in this test indicate that the inclastic material models currently in use in the ABAQUS finitc element analysis program need to be enhanced to morc accurately capture the effects of inelastic strain zeversal. The ABAQUS code developers (Hibbin. Karlsson \& Sorensen. Inc.) are under contract to criance the material modeling capabilitues of the elastic-plastic analysis software. When completc. the correlation of analysis-totest of these models will be updated and reported

\section{REFERENCES}

(1) Solonick. W. R., 1996. "Elastic.Plastuc Strain Acceptance Criterion for Structures Subject to Rapidly Applied Transient Dymamic Loading," Proceedings of IMECE96

(2) Hodgc, S. C., Minicucci, J. M., 1996, "Elastic-Plastıc Finite Elcment Analysis-to-Test Correlation tor Structures Subject to Dynamic Loading," Proceedings of IMECE96 
APPENDIX

IABLE A-1 - Sensor Requirements

\begin{tabular}{|c|c|c|c|}
\hline SENSOR & RANGE & MANUFACTURER & CATALOG NO. \\
\hline $\begin{array}{l}\text { High Elongation } \\
\text { Strain Gages }\end{array}$ & $\begin{array}{l}0 \% \text { To } 15 \% \\
\text { Elongation }\end{array}$ & Micro-Measurements & EP-08-050SB-120 \\
\hline $\begin{array}{l}\text { Uniaxial Strain } \\
\text { Gage Strings }\end{array}$ & $\begin{array}{l}0 \% \text { To 5\% } \\
\text { Elongation }\end{array}$ & Micro-Measurements & EA-XX-125MW-120 \\
\hline $\begin{array}{l}\text { Uniaxial Strain } \\
\text { Gages }\end{array}$ & $\begin{array}{l}0 \% \text { To 5\% } \\
\text { Elongation }\end{array}$ & Micro-Measurements & CEA-06-125UN-350 \\
\hline $\begin{array}{l}\text { Multiaxial Strain } \\
\text { Gage Rosettes } \\
\end{array}$ & $\begin{array}{l}0 \% \text { To } 5 \% \\
\text { Elongation }\end{array}$ & Micro-Measurements & CEA-06-125UR-350 \\
\hline Accelerometers & $\begin{array}{l}0 \text { 7o } 50 \mathrm{~g} \text { 's } \\
0 \text { 7o } 100 \mathrm{~g} \text { 's } \\
0 \text { 7o } 200 \mathrm{~g} \text { 's }\end{array}$ & B \& K $(0.2-4800 \mathrm{~Hz})$ & 4366 \\
\hline $\begin{array}{l}\text { Displacement } \\
\text { Gages }\end{array}$ & $0708.0 \mathrm{in}$ & Schaevitz & $10000 \mathrm{HR}$ \\
\hline $\begin{array}{l}\text { Displacement } \\
\text { Gages }\end{array}$ & 0702.0 in & Schaevitz & $5000 \mathrm{HR}$ \\
\hline
\end{tabular}

TABLE A-2 Summary of Test Results

\begin{tabular}{|c|c|c|c|c|c|c|}
\hline \multirow{3}{*}{$\begin{array}{l}\text { TEST } \\
\text { SPECIMEN }\end{array}$} & \multicolumn{6}{|c|}{ MEASURED PEAK } \\
\hline & \multicolumn{3}{|c|}{ LOAD LEVEL } & \multirow[b]{2}{*}{ STRAIN $(\%)$} & \multirow[b]{2}{*}{ DEFLEC (in) } & \multirow{2}{*}{$\begin{array}{c}\text { PERM. } \\
\text { SET } \\
\text { (in) } \\
\end{array}$} \\
\hline & MAX & $\begin{array}{l}\text { TME } \\
\text { (msec) }\end{array}$ & $\begin{array}{c}\text { AREA } \\
(\mathrm{in} / \mathrm{sec})\end{array}$ & & & \\
\hline CL-1 & $21.3 \mathrm{~g}$ & 92 & 280.9 & 1.31 & 2.74 & 0.186 \\
\hline CL-2 & $26.3 \mathrm{~g}$ & 104 & 299.1 & 1.28 & 3.15 & 0.278 \\
\hline CL-3 & $26.4 \mathrm{~g}$ & 100 & 331.1 & 1.48 & 3.24 & 0.338 \\
\hline $\mathrm{BL}-1$ & $22.6 \mathrm{~g}$ & 96 & 297.5 & 1.31 & 1.09 & 0.213 \\
\hline BL-2 & $22.8 \mathrm{~g}$ & 102 & 297.1 & 2.27 & 1.25 & 0.224 \\
\hline BL-3 & $29.2 \mathrm{~g}$ & 101 & 335.0 & 2.61 & 1.46 & 0.389 \\
\hline $\mathrm{CS}-1$ & $88.3 \mathrm{~g}$ & 12 & 214.4 & 1.89 & $\cdot$ & 0.287 \\
\hline $\mathrm{CS}-2$ & $205 \mathrm{lb}$ & $n / 3$ & n/a & 0.13 & 0.63 & 0.000 \\
\hline $\mathrm{CS}-2$ & $106.5 \mathrm{~g}$ & 12 & 261.5 & 2.73 & - & 0.828 \\
\hline CS-3 & $107 \mathrm{~g}$ & 12 & 258.0 & 2.60 & - & 0.898 \\
\hline CS-4 & $226 \mathrm{~g}$ & 7 & 365.5 & 4.45 & - & 2.790 \\
\hline CS-5 & $742 \mathrm{~g}$ & 3 & 347.8 & 5.23 & - & 3.408 \\
\hline CS-6 & $100 \mathrm{~g}$ & 10 & 254.1 & 2.87 & - & $1.16 * *$ \\
\hline $\mathrm{CS}-7$ & $5.8 \mathrm{~g}$ & 50 & $\mathrm{n} / \mathrm{a}$ & 0.18 & - & 0.000 \\
\hline CS -7 & $158 \mathrm{~g}$ & 9 & 340.0 & 4.17 & . & $2.66 * *$ \\
\hline
\end{tabular}

** permanent set from initial shot (field measured)

STRAIN is total strain (elastic + plastic) 
FIGURE A-1 - Test Specimen Strain Gage Locations
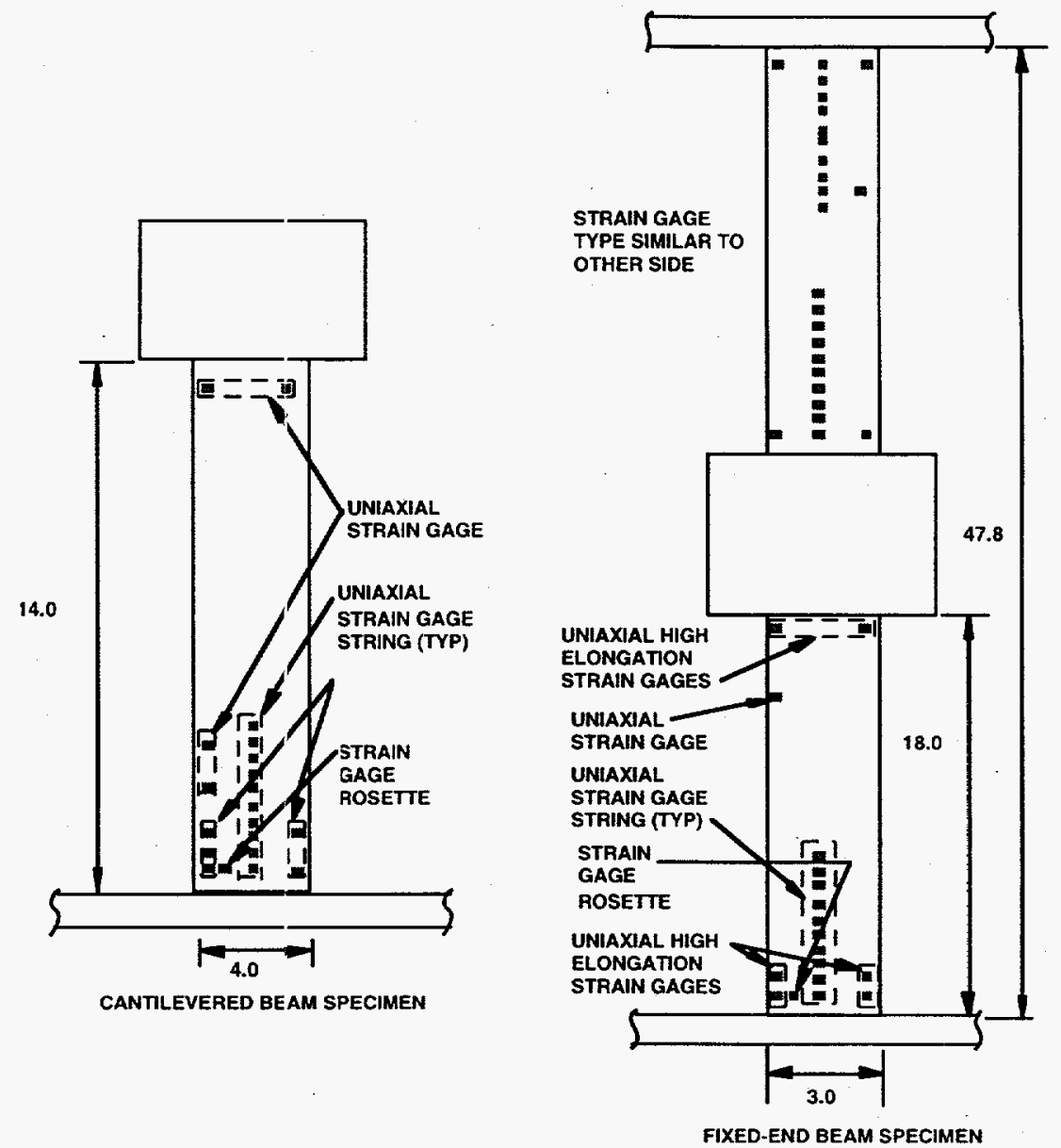